\title{
The Dialectics of the Right of Ownership of Patentable Inventions Under the Nigerian Legal System.
}

\author{
Mary Imelda Obianuju Nwogu ${ }^{1}$ \\ ${ }^{1}$ Faculty of Law, Nnamdi Azikiwe University Awka, Anambra State, Nigeria. \\ Correspondence:Mary Imelda Obianuju Nwogu, Faculty of Law, Nnamdi Azikiwe University Awka, Anambra State, \\ Nigeria.
}

Received: March 5, 2015

Accepted: March25, 2015

Available online: April 8, 2015

doi:10.11114/ijsss.v3i3.758

URL: http://dx.doi.org/10.11114/ijsss.v3i3.758

\begin{abstract}
The grant of the right of patent to an invention is vested in the statutory inventor, employer, commissioner of a work, assignee or licensee. For this right of patent to be granted the invention must be patentable. Patentable inventions are inventions in respect of which patent is granted under the law. Patent is regulated in Nigeria by the Patents and Designs Act (PDA) 2004, which protects inventions that fall within patentable subject matter. An invention is deemed patentable if it is new, results from inventive activity and is capable of industrial application; or if it constitutes an improvement upon a patented invention and it is also new, results from an inventive activity and is capable of industrial application. However, not all inventions are patentable, some are non-patentable and they include plant or animal varieties or essentially biological processes (other than microbiological processes) for the production of plants and animals; or inventions that are contrary to public order or morality.
\end{abstract}

Keywords: Right, ownership, Patentable inventions, Nigeria, Legal system.

\section{Introduction}

Patent is an intellectual property right that is recognised and appreciated throughout the entire globe. It protects ideas and inventions that are novel. Its importance in today's world technology cannot be overemphasised. Industrialization, research and development are aided and sustained by the protection of patent rights, which ensure that every man benefits and reaps the fruits of his labour. Patents are regulated by patents law which concerns itself with the new industrially applicable inventions, which fall under patentable subject matter and meet the requisite standard for patentability.The law that regulates patents in Nigeria is the Patent and Designs Act, 2004.

Patentable inventions are inventions in respect of which the law will grant patent. Patent is granted to an invention that is new or essentially different and better than what existed before, or for a better way of making it. Patent is however, not granted to plant and animal varieties or essential biological processes for the production of plants or animals (other than microbiological processes and other products) and inventions which are against public order and morality. The right to these patentable inventions are subject to ownership by the grant of letter of patent.

\section{What is an Invention}

The meaning of an invention is not provided for under the Nigerian Patents and Designs Act (PDA). But section 2 of the Canadian Patents Act (2013) defines invention as 'any new and useful art, process, machine, manufacture or composition of matter, or any new and useful improvement in any art, process, machine, manufacture or composition of matter'. Like most legal terms scholars are not agreed in particular terms as to the definition of what constitutes an invention. Hence there are varying definitions as there are scholars. Read (2004) states that an invention is the process of devising and producing by independent investigation and experiment something not previously known or existing. In the words of Garner (1999), an invention is a patentable device, or process created through independent effort and characterized, by an extraordinary degree of skill or ingenuity; a newly discovered art or operation. It is also the act or process of creating such a device or process. It embraces the concept of non-obviousness.

To Kur (2008), an invention is a new solution to a technical problem. The problem may be old or new, and one that has never been thought of before or at least if thought of by someone, not made known by him so that it can become accessible to another. It then follows that from a community reading of the definitions, an invention is a new product or 
process that has not been made known or obvious in whatever form, at anytime, anywhere and anyplace before a patent application is made.

It is worthy of note that inventions are distinguishable from discoveries. Inventions are patentable while discoveries are not. Inventions are protected under the law of patents as opposed to discoveries. The philosophy behind this is that:

Inventions are rarely the result of instantaneous stroke of genius. They are usually the result of a long and hard thinking experimentation with a precise aim and hope of arriving at a new solution amounting to an invention. In other words, inventions are usually the result of methodological research. It is not only just, but is also necessary in order to encourage the making of the investment required for research. (WIPO as cited in Kur 2008)

It then means that an invention adds to knowledge, and previously known inventions. This knowledge and ingenuity must be used to produce or cause the production of, either a new and useful thing or result, or a new and useful method of producing an old thing or result. While a discovery adds only knowledge to what previously existed. This distinction was aptly enunciated in Reynolds v Herbert Smith \& Co Ltd1913 as cited in Babafemi (2008), wherein the court held that:

Discovery adds to the amount of human knowledge, but not merely by disclosing something. Invention necessarily involves also the suggestion of an act to be done, and it must be an act which results in a new product, or a new process, or a new combination for producing an old product or an old result.

In addition, S. 1(5) of the Patents and Designs Act (PDA) excludes principles and discoveries of a scientific nature from being inventions. Since they are not inventions they do not qualify for the grant of patent. Also not all inventions qualify for patent grant.

\section{Patentable Inventions}

The Patents and Designs Act (PDA) sets out conditions under which an invention is deemed patentable. Section 1(1) provides that an invention is patentable:

a. If it is new, results from inventive activity and is capable of industrial application:or

b. If it constitutes an improvement upon a patented invention and also is new, results from inventive activity and is capable of industrial application.

The above provision of the PDA is in line with the provision of Article 27(1) of the Agreement on Trade Related-Aspects of Intellectual Property Rights (TRIPS) 1994. TRIPS is a World Trade Organization (WTO) international instrument on intellectual property. Article 27(1) states that patent shall be made available for any inventions whether products or processes, in all fields of technology, provided they are new, involve an inventive step and are capable of industrial application.

Newness or novelty seems to be cardinal in the contemplation of the Patents and Designs Act in the patenting of an invention. The newness of an invention is usually judged against the 'state of the art', that is, existing knowledge. The PDA further provides that:

a. An invention is new if it does not form part of the state of the art:

b. An invention results from an inventive activity if it does not obviously follow from the state of the art, either as to the method, the application, the combination of methods, or the product which it concerns, or as to the industrial result it produces (S. 1(2)(a-b)).

The 'state of the art' as it relates to newness of an invention means:

Everything concerning that art or field of knowledge which has been made available to the public anywhere and at anytime whatever (by means of a written or oral description, by use or in any other way) before the date of the filing of the patent application relating to the invention or foreign priority date validly claimed in respect thereof, so however that an invention shall not be deemed to have been made available to the public merely by reason of the fact that, within the period of six months preceding the filing of a patent application in respect of the invention, the inventor or his successor in title has exhibited it in an official or officially recognized international exhibition (PDA, s.1(3)) 
It then follows from the above provision that publication by oral disclosure or by document or prior use destroys novelty and renders the process or product unpatentable.

This includes matters contained in other patent applications having an earlier priority date. Therefore novelty is really a question of whether the invention has been anticipated, by a previous patent, or by publication or use. The anticipating patent, or publication could occur anywhere in the world. In line with this assertion, Bainbridge (1999) opines that the act or series of acts that make the invention available to the public do not have to be on a particularly, wide scale. Using an invention in public in one locality only will suffice to anticipate patent. In the English case of Windsurfing International Inc v Tabur Marine (Great Britain) Ltd as cited in Bainbridge (1999), the court held that prior use of a sailboard, had effectively anticipated a later patent, and thus declared invalid for want of novelty.

Disclosing an invention orally to someone who has the capacity to pass such information whether fraudulently or inadvertently, notwithstanding the stricture put upon him by the inventor, destroys novelty (Babafemi 2007).In the case of document, it need not be sold for it to be publication, display on a library shelf or mere exhibition in a bookshop suffices. Interestingly, only one exception to publication is provided under the PDA, which is that, an invention is not deemed to have been made available to the public if within six months of filing the patent application the inventor exhibited in an officially recognised international exhibition. However, it is my view that more exceptions should be incorporated into the Act with respect to public disclosure. These should include, where public experimentation is of necessity required to carry out the invention before making application for patentability. Also where in a conference it is required that it must be read to the public for it to be considered and appreciated.

Be that as it may, it is worrisome that the PDA did not stipulate the quantum of disclose of the invention that will defeat novelty, whether it is a substantial part of the invention or the whole invention or any part of the invention. It is important that the Act be amended to include the extent of permissible disclose/disclosure.

In addition, for an invention to be patentable, it must be capable of industrial application. That is, it can be manufactured or used in any kind of industry, including agriculture (PDA, s.1(2)(c)).

Section 1(1)(b) PDA provides that an invention will also be deemed patentable if it constitutes an improvement upon an existing patented invention. It then means that the new process or product should constitute an improvement of the old process or product respectively, in addition to satisfying all the requirements of newness, which includes; non disclosure and non publication by document or prior use, then it qualifies for patent grant. The case of James Oitomen Agbanrofo $v$ Grain Haulage and Transport Ltd (1998) is instructive, wherein the court granted patent to the plaintiff who had invented a harmless electric water boiler that prevents fire disaster, on the grounds that he satisfied the requirement of novelty and industrial applicability.

\section{Right to the Grant of Patent}

The right to patent in Nigeria is vested in the statutory inventor, employer, assignee or licensee.

\subsection{Statutory Inventor}

Section 2(1) of the Patents and Designs Act provides that the right to a patent in respect of an invention is vested in the statutory inventor. It went further to define statutory inventor as the person who, whether or not he is the true inventor, is the first to file or validly to claim a foreign priority for, a patent application in respect of an invention. Foreign priority means when an earlier corresponding patent for the protection of an invention has been made in a convention country, it shall be treated as having been made in Nigeria when that earlier application was made, provided it was made within twelve (12) months before the application in Nigeria (S. 27 PDA). It follows that the yardstick here is the issue of 'filing first', which could be done by any person (either the true inventor or any other). This tends or seems to encourage fraud. But the Act went ahead to protect the true inventor and discourage fraud by the following provisions; S. 2(2) provides that

the true inventor is entitled to be named as such in the patent, whether or not he is also the statutory inventor, and the entitlement shall not be modifiable by contract.

In addition, S. 2(3) also states that the applicant who is not the true inventor must of necessity obtain the consent of the true inventor (or his successor in title) before using his invention to file a patent application. If the said applicant does not do so, all the rights in the application and in any other patent grant in pursuance of it shall be deemed to be transferred to the true inventor or his said successor in title.

In United Kingdom, unlike in Nigeria, the inventor of an invention is by S. 7 (3) of the Patents Act 1977, the actual devisor of the invention. Primarily patent is granted to the inventor or joint inventors, except where someone else has a better entitlement by contract or operation of law (Bainbridge 1999). In the United States of America, the inventor or the person to whom the inventor has assigned or is under an obligation to assign the invention applies for patent (United 
States Patent and Trademark Office, 2014). It is my considered view that Nigeria should expunge the 'first to file claim' from our extant law, and incorporate in our Patents and Designs Act, that patent should be granted primarily to the true inventor as provided under the United Kingdom and United States Laws.

\subsection{Employee Inventor}

Where an invention is made by an employee in the course of his employment or in the execution of a contract for the performance of a specific work, the right to the patent in the invention is vested in the employer or in the person who commissioned the work as the case may be (PDA, s.2(4)). However, it is worthy of note that these rights granted to the employer or commissioner is not absolute, it is subject to exceptions, hence the Act provides thus:

Where the inventor is an employee, then

(a) If -

(i) His contract of employment does not require him to exercise any inventive activity but he has in making the invention used data or means that his employment has put at his disposal; or

(ii) The invention is of exceptional importance,

He is entitled to a fair remuneration taking into account his salary and the importance of the invention; and

(b) The entitlement in question is not modifiable by contract and may be enforced by civil proceedings (PDA, s.2(4)(a-b)).

It is logical and equitable that if the invention has been commissioned or made in the course of one's employment, that is, as part of the employee's job, his employer should be entitled to the patent. On the other hand, if it is not part of the employee's job to make an invention and he uses the material of the employer to make the invention, the right to patent should ordinarily accrue to the employer, because it can be argued that the invention could probably not have been possible without the means or materials of the employer. However, where it is not part of the employee's job to make an invention and he made one without using the materials or data belonging to his employer, the employee should obviously have the right to patent it (Babafemi, 2004).The English case of Greater Glasgow Health Boards' Application (1996) is illustrative, wherein a doctor (a registrar) invented a spacing device for an ophthalmoscope in his own time. The court held that his duty to treat patients does not extend to devising new ways of diagnosing and treating patients, that the doctor is entitled to the proprietor of the patent, for he made the invention in his own time.

Suffice it to state that a knotty issue arises from the provision of S. 2(4)(a) of PDA on, 'invention of exceptional importance'. The PDA did not provide for when an invention will be regarded as being of exceptional importance. Therefore this is subject to varying interpretations depending on one's background. The interpretation given to it by the employer will not be the same with the one given to it by the employee. It is important and good that the Act specifies the meaning of an invention that is of exceptional importance that will entitle the employee-inventor to fair remuneration. Also the provision of the PDA on fair remuneration based on the employee's salary and the importance of the invention is problematic because, firstly, the quantum of the remuneration that will be regarded as fair is subjective depending on the individual concerned. Secondly, the salary of the employee-inventor may be meagre compared to the pecuniary benefit accruing from the invention; this may work injustice to the employee. The importance of the invention may not be immediately evident, it may acquire great importance over time and yield so much money and the true inventor will be at a loss because he is paid once.

However, it is suggested that the quantum of compensation to be given to the employee - inventor in such circumstances should be an agreed percentage between the employee and employer which should be paid annually from the profit that accrues from the invention.

\subsection{Assignees of Inventions}

A person's rights in a patent application maybe assigned, transferred by succession or held in joint ownership (PDA, s.24(1)). An assignment under PDA shall be in writing and signed by the parties (S. 24(2). The said assignment or transfer by succession shall have no effect against third parties unless it has been registered and the prescribed fee paid (S. 24(3)). The above point is adumbrated in Arewa Textiles Plc and Ors V Finetex Limited (2003) as cited in Babafemi wherein the Court of Appeal per Salami JCA held that:

The right to apply for letters of patent in respect of an invention by an assignee thereof under his own name is not a mere moral adjuration. It is a duty under S. 24(1) of the Patents and Designs Act, Cap 344 Laws of the Federation of Nigeria 1990, to register assignment or transfer interest held in joint ownership of a patent. This is because by virtue of Section 24(1) and (3) of the Patents and Designs Act an assignment or transfer thereof shall have no effect against third parties unless it has 
been registered and the prescribed fees paid. In the instant case there is no evidence of such registration and payment of the requisite fees before the court and in the absence of such vital evidence, the respondent's cause of action against the appellants is inchoate because the assignment could have no effect.

\subsection{Contractual Licensee}

A patentee may by a written contract signed by parties grant a licence to any person to exploit the relevant invention (PDA,s.23(1)(a)).However, in the absence of any provision to the contrary in the contract, the licensee shall be entitled to do anywhere in Nigeria in relation to the patent any of the acts exclusively preserved for the patentee under the Patents and Designs Act (S. 23(1)(b)). However, where a licence is granted as provided above, the licence shall be registered, and shall be of no effect against third parties until registration is effected and the prescribed fee paid (S. 23(2)(a)). This registration shall be cancelled at the request of the licensor, if the registrar is satisfied that the licence has been terminated (s.23(2)(b)).Moreover, in the absence of any provision to the contrary in a contract -

(a) The grant of the licence shall not prevent the licensor from -

(i) Granting further licences to other persons: or

(ii) Himself exploiting the relevant patent

(iii) The licence shall not be assignable by the licensee; and

(iv) The licensee shall not be entitled to grant further licences (PDA s. 23(4).

Flowing from the above provision the licensor, unless otherwise prohibited by contract, may grant further licences to other persons and also exploit the relevant patent himself. While the licensee, unless otherwise permitted by contract cannot assign or sub-let the licence granted to him.

Furthermore, Babafemi (2007) posits that contractual licence may be general or limited in scope. A general contractual licence is one that grants to the licensee the power to use the patented invention in all its parts, in any manner and to any extent throughout the whole territory for which the patent monopoly was granted. On the other hand a limited contractual licence is the one that is limited in its scope. The limitation may also be justified by the interest of the licensor in the technically efficient exploitation of the subject of the patent (PDA, s.23(3)).

\section{Application for Grant of Patent}

The application for the grant of patent shall be made to the Registrar of Patents and Designs (PDA, s.3(1)(a)) in form 1(PDA, Rule 8(1)) and shall contain:

(a) The applicant's full name and address and if that address is outside Nigeria, an address for service in Nigeria (PDA, s.3(1)(a)).

(b) A description of the relevant invention with any appropriate plans and drawings.

(c) A claim (Rule 8(1)).This claim(s) shall define the protection sought and shall not go beyond the limits of the said description (Rule 12(2)).

The application shall be accompanied by the prescribed fees; where appropriate, a declaration signed by the true inventor requesting that he be mentioned as such in the patent and giving his name and address; and if the application is made by an agent, a signed power of attorney authorizing the donee to that effect (S. 3(1)(b)). In addition, the description referred to above shall disclose the relevant invention in a manner sufficiently clear and complete for the invention to be put into effect by any person skilled in the art or field of knowledge to which the invention relates (S. $3(2))$.

Where the applicant seeks to avail himself of a foreign priority in respect of earlier application made in a country outside Nigeria, he should attach to his duly made application the date, country and number of the earlier application; and the name of the person who made the earlier application; not more than three months after making the application under S. 3(1) of PDA, he shall present to the Registrar with a copy of the application certified correct by the Industrial Property Office (IPO) in the country where the earlier application was made (S.3(4)). The Registrar examines every patent application as to its conformity with the relevant provisions of PDA. Where it conforms, the patent shall be granted as applied, but if it does not conform the application shall be rejected or amendments made, depending on the extent of the non-conformity (S. 4(1-2)).

There is no gainsaying that the grant of patent to an invention brings about development and technological advancement, because there is dissemination of information and at the same time the protection of the patentees right to an invention, thereby increasing his pecuniary benefits. In line with this assertion, Nwogu (2014) states that patent grant encourages 
investments by private sector, especially for an easily copied invention. It also encourages access to invention produced elsewhere. Further, the presence of strong and effective patent system brings about the dissemination of information and provides incentive to invest in the development of new processes and products.

Patents are also valuable because they offer numerous opportunities for all to gain access to new markets, especially for companies who own patents on technology they cannot manufacture or have intention of producing. Patent system is also meant to encourage investment of resources in making new inventions or importing new technologies into a country.

\section{The Rights of a Patentee}

A patentee is a person to whom a patent has been granted. This is done by the Registrar after the patent application has been thoroughly scrutinized and found to have satisfied the requisite conditions. Section 32 of the Patents and Designs Act provides unequivocally thus, that a patentee 'means a person to whom a patent has been granted'. When granted, it confers upon the patentee the right to preclude any other person from engaging in any of the following acts thereof:

a. Where the patent has been granted in respect of a product, the act of making, importing, selling or using the product, or stocking it for the purpose of sale or use; and

b. Where the patent has been granted in respect of a process, the act of applying the process or doing, in respect of a product obtained directly by means of the process, any other acts as in (a) above (S.6(1)).

The above provision has been modified in compliance with Article 28(1) of TRIPS, which provides for rights conferred on a patentee; these rights include, if it is a product, to prevent third parties not having the patentee's consent from the acts of making, using, offering for sale, selling, or importing for these purposes that product. If it is a process, to prevent third parties not having the right owner's consent from the acts of using the process, and from using, selling, offering for sale, or importing the product obtained directly from this process. Also Article 28(2) states that, patent owners shall also have the right to assign, or transfer by succession, the patent and to conclude licensing contracts as stated in section 24 and 23 of PDA respectively.

The right granted to a patentee does not enure in perpetuity. The patentee enjoys the above stated rights for the duration of the patent granted, which is twenty years counting from the date of filing the patent application (PDA, s. 7(1)).Except where the patent lapses (PDA,s.7) or is surrendered (PDA,s. 8) or is declared a nullity by a court with requisite jurisdiction (PDA,s. 9). By the provision of S.7(2) of the PDA a patent lapses if the prescibed annual fees are not duly paid after a period of six months of grace. But if these fees and any surcharge are paid within the specified period, the patent shall continue as if the fees where duly paid. S. 8(1) provides that a patent may be surrendered by a patentee by written declaration addressed to the Registrar. Also s. 9 states that a patent shall be declared null and void by a court of competent jurisdiction on the application of any person, if the subject of the patent is not patentable, or the description of the invention; or the claim does not disclose the relevant invention in a manner sufficiently clear and complete for the invention to be put into effect; or that a patent has been granted for thesame invention before.

It is important to note that the grant of this exclusive right to work an invention for a period of time, constitutes an important incentive to inventive and innovative activity. It also enables the inventor to exact a premium for, and thus recover initial research and development (R\&D) costs, and thus acts as a stimulus to the undertaking of further research and development (International Bureau of WIPO, 1997). However, the right granted to a patentee is not absolute, it is subject to exceptions.

\section{Exception to the Exclusive Rights of a Patentee}

\subsection{Compulsory Licence}

There has always been seeming danger that the proprietor of a patent (or patentee) may abuse the monopoly granted to him. For an inventor may patent his invention and not make it available to the public and prevent anyone else from doing same. This is in outright contradictions of the intendment of the patent law. The object of patenting is to encourage the development of new industries and technology generally. To curb this anomaly and encourage dissemination of information, process and products the PDA provides for compulsory licences under which others may work the invention against the wish of the patentee. Hence,Paragraph 1 of the First Schedule of the Patents and Designs Act provides that any person (third party) can apply to the court at any time after the expiration of a period of four years after the filing of a patent application or three years after the grant of a patent, whichever period expires last, on one or more of the following grounds -

(a) that the patented invention, being capable of being worked in Nigeria, has not been so worked;

(b) that the existing degree of working of the patented invention in Nigeria does not meet on reasonable terms the demand for the product. 
(c) that the working of the patented invention in Nigeria is being hindered or prevented by the importation of the patented article; and

(d) that, by reason of the refusal of the patentee to grant licenses on reasonable terms, the establishment or development of industrial or commercial activities in Nigeria is unfairly and substantially prejudiced

Paragraph 14 of the same First Schedule, provides that working of a patented invention means:

(a) the manufacture of a patented article; or

(b) the application of a patented process; or

(c) the use in manufacture of a patented machine;

by an effective and serious establishment in Nigeria on a scale which is adequate and reasonable in the circumstance.

However, compulsory licence is granted not just for the prevention of the abuse of patent right by the patentee, but also in response to national emergency (First Schedule Para 20), such as war and health emergency. For example, in cases of disease outbreak, like when a deadly disease called Ebola came into Nigeria. Such a situation should be declared a national health emergency that empowers the Federal Government to grant compulsory licences for the manufacture of drugs for the treatment and prevention of such ailment without the consent of the patentee (right holder).

However, in making an application for the grant of compulsory licence to the court, the applicant must satisfy the court that he has attempted to obtain contractual licence from the patentee and has been unable within a reasonable time and on reasonable terms. The applicant will also offer guarantees that satisfy the court, that he will work the patent to cure the deficiencies that gave rise to the application (Para, 5(a-b)).

Reasonable time and reasonable terms have not been defined by the Patents and Designs Act. This makes the two terms otiose and ambiguous. Reasonable term or time could be defined with regards to the view of an ordinary reasonable man on the street, depending on the circumstance of the case. The court is empowered and can effectively determine the reasonability of a situation on its own merit.

Furthermore, a compulsory licence shall not be granted in respect of a patent if the patentee satisfies the court that his actions in relation to the patented invention are justifiable in the circumstance, but he cannot be seen to have so satisfied the court by merely showing that the patented article is freely available for importation (Para, 4).

The grant of compulsory licence is given effect by the Agreement on Trade-Related Aspects of Intellectual Property Rights (TRIPS) 1994 in its Articles 30 and 31.. Article 30 of TRIPS provides thus:

Members may provide limited exceptions to the exclusive rights conferred by a patent, provided that such exceptions do not unreasonably conflict with a normal exploitation of the patent and do not unreasonably prejudice the legitimate interests of the patent owner, taking account of the legitimate interest of third parties.

Further, Article 31 (a-c) states that where the law of a member state allows for another's use of a patented invention without the authorization of the right holder, including the use by the government. The authorization of such use shall be considered on its individual merits. The use may only be permitted if before the use the applicant has sought the authorization of the patentee on reasonable commercial terms and conditions, which has failed within a reasonable period of time. This requirement may be waived in national emergency situations or circumstances of extreme urgency or in cases of public non-commercial use. In cases of national emergency and other circumstance of extreme emergency the right holder should be notified as soon as reasonably practicable in the case of public non-commercial use, where the government or contractor, without making a patent search, knows or has demonstrable grounds to know that a valid patent is or will be used by or for the government, the patentee shall be informed promptly.

In addition, under Article 31 (d-j) of TRIPS compulsory licence shall be non-exclusive, non-assignable, authorized predominantly for the supply of the domestic market of the member state authorizing such use. This use shall terminate when the circumstances which led to it cease to exist and are unlikely to reoccur. Compensation or adequate remuneration shall be paid to the right holder,taking into account the economic value of the compensation and the legal validity ofthe decision to grant compulsory licence and the decision on remuneration are subject to judicial review.

Reasonable period of time has also posed a problem. The TRIPS Agreement did not provide for the meaning of the term. This will definitely subject the term to varying degrees of application and interpretation. It is my view that this term should be interpreted based on the national law and circumstance of each member state.

Suffice it to state that for a compulsory licence to be granted to an applicant the court considering such an application must be satisfied that the requisite and necessary conditions for such a grant of licence exists.On the other hand, a right holder who refused to grant a contractual licence can approach the court to maintain his stand. If the applicant did not 
satisfy the conditions necessary for the grant or the patentee's refusal is right in the eye of the court, the court will refuse to grant the compulsory licence. But if all the conditions are fulfilled and the court is not satisfied with the right holder's position, the court will grant the compulsory licence. Further, it is worthy of note that after granting a compulsory licence, the patentee may apply to the court to cancel the compulsory licence; if the licensee fails to comply with the terms of the licence or the conditions that justified the grant has ceased to exist (First Schedule, Para 9).

Another exception to the exclusive rights of a Patentee is provided under Patents and Designs Act thus:

Where, at the date of filing of a patent application in respect of a product or process or at the date of foreign priority validly claimed in respect of the application, a person other than the applicant -

(a) was conducting an undertaking in Nigeria; and

(b) in good faith and for the purpose of the undertaking, was manufacturing the product or applying the process or had made serious preparations with a view to doing so,

then notwithstanding the grant of patent, there shall exist a right (exercisable by the person for the time being conducting the undertaking, and not otherwise) to continue the manufacture or application, or to continue and complete the preparation, and thereafter undertake the manufacture or application as the case may be, and in respect of any resulting products to do any other act exclusive to the patentee.

Also paragraphs 15 and 16 of the First Schedule of PDA state that the Minister will in the public interest authorize any person to use any patented invention, before or after the relevant patent has been granted for the service of a government agency in the Federal Republic of Nigeria.

\subsection{Rights of a Compulsory Licensee}

A person that has been granted a compulsory licence or a compulsory licensee shall have all the rights granted to a patentee under PDA as has been discussed earlier in this work. But this does not entitle the licensee to grant further licences to third parties or import the product in question: the licence is non-exclusive, which implies that the original patentee has the right to use and deal with the patent the way he deems fit, even licensing to another person (Para, 6).

However, a compulsory licence may be transferred only with the industrial undertaking in which the relevant invention is used and no such transfer shall be valid until the consent of the court has been sought and obtained (Para,7).

There is no gainsaying from the discussions above that some of the provisions of the Patents and Designs Act (PDA) on compulsory licence, particularly paragraphs 1,4,5, 6 and 15 of the First Schedule are modeled in line with Articles 31 and 32 of TRIPS Agreement. Except that there is no provision on remunerating the original patentee under the Patents and Designs Act. It is my considered view that the provision on remunerating or compensating the original patentee should be incorporated into PDA, because the right owner deserves pecuniary benefits from the fruits of his labour. This will also encourage investments and further inventions that are patentable.It is also trite law that when something is taken away from somebody under the law without his/her consent, that person must be compensated. For example; this is evident in S. 29 of the Land Use Act 1978, which provides for compensation when somebody's right of occupancy is revoked by the government. It is worthy of note that not all inventions are patentable, some are non patentable.

\section{Non-Patentable Inventions}

The Patent and Designs Act in its S. 1(4) has also enumerated inventions to which patent cannot be granted. It provides that patent cannot be validly obtained in respect of:

a. Plant or animal varieties or essentially biological processes for the production of plants or animals (other than microbiological processes and their products): or

b. Inventions, the publication or exploitation of which would be contrary to public order or morality (it being understood for the purposes of this paragraph that the exploitation of an invention is not contrary to public order or morality merely because its exploitation is prohibited by law).

The above provisions are problematic to deal with. The issues are' what are "essentially biological processes"? What are microbiological processes"? Are they materially different from one another, that the latter merit the grant of patents and the former do not. This problem is compounded by the fact that the Patents and Designs Act does not provide for the meaning of the two concepts. However, micro-organisms can be considered to be very small, independent units that are not visible to the naked eye, they are patentable by some form of human intervention. Genetic engineering processes are also patentable. Biological processes are processes occurring in living organisms (Thesuarus 2014). While microbiological process is any process involving or performed upon or resulting in microbiological material (Rule 26 of the European Patent Convention 2013). 
The exclusion in S.I (4) (b) PDA is on policy grounds. It involves something more than mere illegality. The PDA does not provide the yardstick for defining public order and morality, or how it will be measured for purposes of patentability. This is very crucial in Nigeria, that is multi-ethnic, multi-lingual and multi-religious, because the parameters for measuring morality differ among ethnic groups, language groups and religious groups. In my view public order may mean independent judicial system, political system, good government, economic policy and proper conduct of affairs for the well being of the polity.

\section{Conclusion}

The dawn of industrial revolution for the protection of inventions brought about the use of Patents law by man. Patents law is used, especially to protect inventions that have commercial value and benefit. This is to protect the fruit of inventive ingenuity of the inventor and encourage further creativity, so that one reaps where he sows. It also deters free-riders, that often times reap where they do not sow. A mordern and effective patent system promotes economic and social progress. Hence the International Bureau of WIPO 1997, posits that technologicl innovation and inventive activity are but two of the factors determining economic and social progress. That inventive activity is the driving force for change and should be encouraged and promoted at all levels.

The Patent and Designs Act provides for patentable and non-patentable inventions. An invention is patentable if it does not form part of the state of the art, does not obviously follow from the state of the art and can be manufactured or used in any kind of industry, including agriculture. While non-patentable inventions are plants or animals varieties or essentially biological processes, excluding microbiological processes; or inventions that are contrary to public order or morality.

Patents are granted to patentable inventions if applications are made to the Registrar of Patents. The Registrar then examines these applications as to its conformity with the relevant provisions of the PDA before the grant. Those who make application for grant of patents are the statutory inventor, employer, assignee and licensee. In Nigeria, primarily the statutory inventor owns the right ofpatent to an invention, which is in contradistiction with the situation in the UK and USA where primarily the true inventor owns patent to an invention.

The provision of non-patentable inventions reduces technology transfer and frustrates research and development. It is important that the PDA made in the mid of the $20^{\text {th }}$ century be upgraded and modified to be in tune with the technological realities and challenges of the $21^{\text {st }}$ century, of which patentability is one of them. Ownership of patent should be vested primarily in the true inventor. The issue of remunerating or compensating the true inventor in the grant of compulsory licence to third parties should be incorporated as provided in TRIPS. Also 'Newness' should be removed as a criterion for patentability and replaced by 'distinctiveness' as posited by Nwogu (2014). The public should be enlightened on the criteria for patentability, its benefits and the method of application. They should also be educated on the disadvantage of any form of disclosure.

\section{References}

Agbanrofo v Grain Haulage and Transport Ltd (1998). FHCL 236.

Agreement on Trade Related-Aspects of Intellectual Property Rights (TRIPS) 1994.

Babafemi, F. O. (2007). Intellectual Property.Ibadan: Justin Book Limited.

Bainbridge, D. I. (1999). Intellectual Property ( $4^{\text {th }}$ ed) England: Pitman Publishing.

Canadian Patents Act (2013). Justice Law website. Law-lois.justice.gc.ca/eng/acts/p-4/FullText.html

European Patent Convention (2013). Deneral and Definitions. http://www.epo.org/law-practice/legal text/html/epc/2013/e/r.26.

Garner, B. A. (1999). Black's Law Dictionary (7 $7^{\text {th }}$ ed). St. Paul Minn: West Group

Greater Glasgow Health Boards' Application(1996) RPC 207.

International Bureau of WIPO (1997). WIPO's Development Cooperation Programme in Respect of the Promotion of Inventive and Innovative Activity. Proceedings of the WIPO African Regional Seminar for Inventors and Researchers. http://www.wipo_ip_msu-97_8-2.doc.

Kur, J. J. (2008). Globalization of Intellectual Property Rights and Regime for the Protection of New Plant Varieties: A Nigerian Perspective.Journal of Private and Public Law, Benue State University, 217-239.

Land Use Act Cap L5 Laws of the Federation of Nigeria (2004).

Nwogu, M. I. O (2014). The Role of the Nigerian Patents Law in Biotechnology Transfer. Journal of Law, Policy and Globalization. (iiste journals),31, 121-124. 
Patents Act (UK) (1977). Patents and Designs Act Cap P1 Laws of the Federation of Nigeria 2004.

Read, A.W. (2004). The New International Websters Comprehensive Dictionary of the English (Encyclopedic Ed).

Florida: Typhoon International .

Thesaurus (2014). The Free Online Dictionary and Encyclopedia. www.thefreeonlinedictionary.com.

United States Patent and Trademark Office(USPTO) (2014). General Information Concerning Patents: Who May Apply for a Patent. Getting Started with Patent. http://www.uspto.gov/patents-gettingstarted/general information.

\section{(cc) $\mathrm{EY}$}

This work is licensed under a Creative Commons Attribution 3.0 License. 